\title{
Useful resources
}

UK

Motor Neurone Disease Association

Tel: +44 (0)1604 250505

enquiries@mndassociation.org

www.mndassociation.org

MND Scotland

Tel: +44 (0)1413323903

info@mndscotland.org.uk

www.mndscotland.org.uk

USA

ALS Association

Toll free (care services/research

questions): 18007824747

www.alsa.org

ALS Therapy Development Institute

Tel: +1 6174417200

info@als.net

www.als.net/resources
Muscular Dystrophy Association

Toll free: 18005721717

www.mda.org/disease/amyotrophic-

lateral-sclerosis

Northeast ALS Consortium (NEALS)

Toll-free (clinical trial liaison):

18554374823

Tel: +1 6178584277

alstrials@neals.org

www.neals.org

International

Motor Neurone Disease Australia

Tel: +61 282874980

Tel (research): +61282874989

info@mndaustralia.org.au

www.mndaust.asn.au

\section{FastTest}

You've read the book ... now test yourself with key questions from the authors

- Go to the FastTest for this title FREE at karger.com/fastfacts

- Approximate time $\mathbf{1 0}$ minutes

- For best retention of the key issues, try taking the FastTest before and after reading 